Halina Gąsiorowska

University of Social Sciences and Humanities \& University of Warsaw

Warsaw, Poland

h.gasiorowska1@wp.pl

\title{
HOMELESS BLOGS AS TRAVELOGUES. TRAVEL AS A STRUGGLE FOR RECOGNITION AND EMPLACEMENT
}

\section{Recommended Citation}

Gąsiorowska, Halina. "Homeless Blogs as Travelogues. Travel as A Struggle for Recognition and Emplacement”. Metacritic Journal for Comparative Studies and Theory 3.1 (2017): https://doi.org/10.24193/mjcst.2017.3.01

\begin{abstract}
Applying Clifford's broad concept of travel, I discuss American homeless blogs as autobiographical travel writing serving the struggle for recognition of the street people. The analysed travelogues are hitchhiker Ruth Rader's Ruthie in the Sky blog and self-made woman Brianna Karp's Girl's Guide to Homelessness - a memoir published on the basis of the blog bearing the same title. In the travelogues I analyse the characteristic features of a personal travel writing: travel of the self, advice for future travellers, geographic information and portrayal of society in which the travel is undertaken. I claim that homeless bloggers recounting their stories of otherness and displacement in the US contribute to (re)constructing American cultural identity their personal Self, just like many other American travellers before. Additionally, homeless blogging about homelessness is shown as the process of emplacement (Casey) - the bloggers' attempt of making themselves at home in the world.
\end{abstract}

Key words: homeless blog, autobiographical travelogue, struggle for recognition, emplacement tramp, self-made (wo)man

Homeless blogs - the personal blogs written by the homeless about their experiences of homelessness - started to appear as early as in the 1990s, but it was not before the economic crises of 2007 when the bloggers became media sensations in 
the US. Researchers recognized homeless blogs as a new media genre (Maurer 122127). The bloggers are perceived as activists struggling for recognition of the street people as well as individuals in need who take care of their own identity.

In this paper, I am going to discuss homeless blogs as travel writing. The travelogues chosen for analysis are: Ruthie in the Sky blog and Brianna Karp's Girl's Guide to Homelessness - a memoir published on the basis of the blog bearing the same title. The selected texts represent very different types of homelessness and for recognition. Ruth has been a homeless hitchhiker since 1994, while Brianna Karp has lived in a trailer stationed at a Walmart parking lot after losing her job in 2008 due to economic crises. Ruthie's story reminds us of a tramp's autobiography, while Karp's memoire is a romance, without a happy ending, a story of becoming a spoke person for the homeless rights as well as a downsized version of the "from rags to riches myth”. Despite the differences between the narratives, both qualify as a story of a travel. Ruthie usually is hitch-hiking between the western and the eastern coast of the US, while Brianna used to camp in her trailer in California, but also took trips to New York City, Scotland and London. I am going to show the features of the travel stories that let us classify Ruthie in the Sky and Girl's Guide to Homelessness as autobiographical travelogues as well as discuss self-portraits of their authors and their vision of the US and American society.

\section{Displacement as a travel}

James Clifford in his book Routes, Travel and Translation in the Late Twentieth Century discusses the notion of travel. He treats it as a translation term, meaning "a word of apparently general application used for comparison in a strategic and contingent way" (39). Such approach allows him to consider as travelers those who previously were excluded from the group, for example a servant of a bourgeois itinerant on the Ground Tour or an Asian laborer coming to the U.S. (33-35). Traditionally, travel and travel writing were perceived as endeavors of the bourgeois class (34). The anthropologist's broad use of the notion of travel embraces not only journey of the unprivileged, migrants and refugees, but also displacement of a person entering a foreign diaspora or a community located in his or her homeland (82). 
I apply Clifford's understanding of traveling to homeless people's displacement: loss of home, community, social network and social standing. A person who has just lost his/her home experiences social and spacial mobility. Those new to life on the streets fall down the social ladder. However, the upward mobility may also become a story of a street person. Social mobility is one of the causes of traveling in its literal sense. Becoming a homeless person means moving out, and sometimes going to another town or state in search for a job and a stroke of luck.

Many homeless bloggers describing their situation, make references to traveling or tourism. For example, Brianna Karp published Girl's GUIDE to homelessness. Another blogger writes under the nickname: Outdoorsman ${ }^{1}$. Ruth Rader, jokingly addresses her readers: Hey, campers! Such references are often ironic, since the bloggers are not tourists. However, the irony does not erase the experience of wandering, but it points out a street person's status as an outcast. According to Kathleen Arnold, the homeless lose their citizenship and become the Other (3-4). Psychoanalytical theories (Lacan, Kristeva, Ahmed) show the Other as constitutive to the Self. I claim that homeless bloggers recounting their stories of otherness and displacement in the U.S. contribute to (re)constructing American cultural identity. As Clifford states, "Practices of displacement might emerge as constitutive of cultural meanings rather than as their simple transfer or extension" (3).

Clifford perceives travel writing and anthropologist's work to be related (68). Travel writers similar to anthropologists engage in "writing cultures" $(23,61)$. The self and other belong to dominant themes in travelogues. Travel writing has taken part in shaping cultural identity of many societies, but it is believed that the genre played especially significant role in forming the Americans' collective self (Thompson 51). As Judith Hamara and Alfred Bendixen noticed, "travel and the construction of American identity are intimately linked" (1). Moreover, "an enabling fiction of «Americanness» frequently works synecdochally with the portrayal of the traveler: the traveler's persona stands in for Americanness" (5). A tramp and a hobo as well as a self-made man belong to the American travelers. I find their stories: an

${ }^{1}$ See PDX Urban Outdoorsman blog https://pdxurbanoutdoorsman.wordpress.com 
autobiography of a tramp and the "from rags to riches" myth/ autobiography of a selfmade man to be among many predecessors of a homeless blog. Although tramp and a self-made man seem to constitute a graphic opposition, both of them experience social mobility. They share features useful for someone in transition: strong spirit and the ability to cope with difficulties. "From rags to riches" tales as well as tramps' autobiographies have played the same function in the $19^{\text {th }}$ and early $20^{\text {th }}$ century as today's homeless blogs. All the narratives undermine negative stereotypes of the homeless as lazy, unintelligent and irresponsible people of bad moral standing.

\section{Homeless bloggers as self-made (wo)men}

Stories of upward mobility are crucial for the American culture built on the perception of the US as the land of opportunity. The myth "form rags to riches" has been reiterated countless times since Horatio Alger wrote about ragged boys working hard to climb the social ladder. Benjamin Franklin's Poor Richard Almanac inaugurated a long line of American self-help handbooks on how to improve oneself. The genre became especially popular in Gilded Era and propagated a self-made businessman as the ideal that young men eager for success in life should pursue (Wyllie 34-42).

Today many homeless bloggers tell their own version of the "from rags to riches myth". The bloggers present themselves as characters sharing with American self-made man precious qualities: solid work-ethic, honesty, determination in pursuing one's goal, self-reliance, the will for self-improvement. American homeless bloggers seem to hope that their cultivated talents (of a journalist, writer or advocate of street people's rights), hard work and self-taught skills in social media marketing should lead them to better life. Many homeless bloggers would like to publish a book based on their blogging. Brianna Karp is one of the very few successful homeless bloggers who published their life-story. The title of her memoire suggests a self-help handbook. Although the book itself did not allow her to move into a house, it shows Karp as a self-made woman. Brianna reveals in the book her gloomy childhood, full of abuse which made her an incredibly strong and self-reliant person. (She started working as a 10-year-old illegally. When Brianna turned 12 her mom obtained a legal job permit for the girl and made the child work full time in order to provide for the 
whole family.) Coming from a family who had little appreciation of to education she had to put herself through college. In her memoire the homeless girls explicitly state she is capable of pulling herself up by her bootstraps (382). Although not many homeless bloggers succeeded in publishing books, the story which ends with getting a job and a house by someone who did not give up and tried hard also supports the selfmade man myth. However, not all the homeless bloggers retell the story. Some, like Ruth Rader, prefer to lead adventurous tramp's life.

\section{Tramps and homeless bloggers}

Tramps as migrant temp-workers commenced wondering across the US after the Civil War in the Gilded Age. They used to risk hopping trains and travel as freeriders. Probably in the 1880 s (Pastino 65) the term „tramp” gained its specificity and began to denote a person who "wonders and dreams" as opposed to a hobo who "wonders and works" and a bum who stays put and does not work, but drinks (Anderson 87). Nels Anderson presents the classification in his study of hoboes of the 1920s quoting Dr Ben L. Reitman, "who has himself travelled as a tramp" and St. John Tucker, "formerly the president of the "Hobo College» in Chicago" (Reitman 87). Anderson himself had experienced hobo's life before becoming a sociologist. Tramps' and hoboes' life-stories were told by ethnographers and the unemployed travellers themselves. The autobiographies of tramps appeared at the turn of the century - at the time of nostalgia for open frontier and adventurous life in which a man could prove himself. Jack London's Road significantly contributed to the tramp's image as a free-spirit having the nerve to break social rules and conventions (Kusmer 178-179).

Ruthie in the Sky blog evokes tramps' autobiography. To Ruth traveling means life. On the road she interacts with people, gathers experiences, admires the world. After choosing the road over her social welfare apartment, where she was not able to make herself home, Ruth writes:

...So where am I going to go now? Back on the road, of course. I'm going to step slow and walk free.... Now that the $\mathrm{H} 1 \mathrm{~N} 1$ virus is slinking like a sick snake across North America...I'm going to take Tour Guide, a backpack and my new walking stick out onto 
the open highway. I'm going to celebrate the LIFE that God gave to me (Ruthie Leaves Nyssa, May 4th 2009).

By pointing to tramp autobiography as a one of the predecessors of a homeless blog by no means would I like to suggest that wanderlust, desire for freedom and a sense of adventure drive all homeless bloggers and keep them from settlement. However, most of the bloggers reiterate some of the motifs characteristic for a tramp's autobiography: longing for home, hardship of life, advices and tips useful for homeless travelers, positive self-image. Moreover, a tramp autobiography was the first medium of the homeless traditionally deprived of the right to speak for themselves. Before the nostalgia for open frontier hit Americans, the 19th century American discourse on tramps and hoboes had presented them in extremely unfavorable manner, dictated by moral panic (de Pastino 20-27).

Today modern homeless blogs, just like tramps' autobiographies of the beginning of the 2oth century, serve as a gate to public sphere for the so-far invisible ones. In contrast to tramps' autobiographies, homeless blogs and their authors immediately received sympathetic and significant publicity. Journalists' ability to make news (and a sensation) of street people blogging reflects stereotypes of a homeless person as an illiterate and unintelligent barbarian - the Other who allows for constituting the identity of citizens as home-owners capable of speaking reasonably in public sphere (for example in social media). Such function of the homeless seems to be created in the 19th century discourse of tramp scare. Todd de Pastino's analysis of discourse on tramps of that time reveals their role in shaping American identity and citizenship (17-25).

Todd de Pastino notices that, in the late 19th century America, tramps were perceived as a danger to civilization and an indicator of failure of hopes associated with free labor after abolishing slavery (18-20). Middle class moral panic produced stories of indulgence, promiscuity, and rebelliousness of masculine tramps who deprived of feminine sphere of home reduced themselves to savages prone to violence (25-27). Tramps were blamed for riots which broke out in many American cities in 1877 as part of class struggle (24). Even the labor press which understood tramping as a product of capitalism, presented the tramps as a threat to good wages and 
employment (33). In the myth of the 19th century progress and modernization housed citizens belonged to civilization with its complementary spheres: work and home, while tramps posed danger to the system (26). A female tramp was especially dangerous to the concept of society and nation. As Tim Creswell notices, such a character kept transgressing the norms of citizenship and gender roles $(184,190)$. Stereotype of female tramps condemned them for their alleged prostitution. Homeless women on the road were often sexually abused (186). The attitude to them has not changed even in times of nostalgia for open frontier, when hoboes began to symbolize traditional American male virtues.

In the paper, I focus on online writing by homeless women on the road, because they constitute a double otherness due to their class and gender. Speaking from farther margins than men living in the streets, women may reveal usually unnoticed or omitted aspects of a homeless person's travel as well as the American culture. The marginal position of the travelers is well exposed in a modern autobiographical travelogue.

\section{Travelogue and autobiography}

Literary critics distinguish two modes of modern travelogues. One focuses on reporting what has been seen, presents detailed descriptions and scientific-like observations. The other one has autobiographical character, and is concerned with traveling self as much (if not more) as with the road itself (Thompson 98). The personal type of travelogues developed after the end of the 18th century. The time is marked in history of literature as the "inward turn" (99).

Homeless bloggers usually follow the style created in the "inward turn". Their travelogues belong to life-writing. Modern travelogue may be classified as a subcategory of life writing ${ }^{2}$ (97). The well-known motif of travel as life makes life (autobiographical) writing such as a personal homeless blog a travel writing. Michel de Certeau calls all writing travel writing, because writing is a kind of a travel (qtd. in Thompson 24). However, the homeless blogs are autobiographical in the literal sense

\footnotetext{
${ }^{2}$ Paul Fussel is an author of the classification. Paul Fussell. Abroad: British Literary Travelling Between the Wars, Oxford: Oxford University Press 1980 qtd. in Thompson 97.
} 
METACRITIC JOURNAL FOR COMPARATIVE STUDIES AND THEORY 3.1

of the term. The personal character of homeless travelogues seems to be the consequence of the bloggers' struggle for individual and group recognition. 


\section{Personal travelogues and the struggle for recognition}

Brianna Karp advices homeless people to avoid drawing attention and to blend in the society. Karp's strategy of survival as hiding her homelessness might seem quite unusual for a person who became a homeless activist, a blogger, an author of a book and a celebrity. Nevertheless, she began blogging anonymously. Karp was exposed as a homeless person against her will by an unhoused activist who travels across the US to make video-interviews with street people which he posts on his website. Although Brianna does not reveal the activist's name, it is not difficult to guess that she was interviewed by Mark Horvath - the founder of Invisible People TV video-blog. According to Karp, the filmmaker broke his promise not to disclose her name in the video. Brianna was upset with the involuntary coming-out because she was afraid that it would compromise her safety as a single woman staying in a trailer as well as jeopardize her chance for future employment.

Just like Brianna at the beginning of her social media activism, Ruthie hesitates between exposing herself and hiding, except that most of the time contrary to the young girl with a trailer, she as a hitchhiker in her 6os carrying all her belongings cannot pass for a housed citizen. Therefore, hiding has a very literal meaning in Ruth's case. When a policeman dropped Ruth off in the middle of nowhere she had to make up her mind whether to stay invisible or draw attention to herself in hope for a lift. She takes both options into account, trying to figure out how they would affect her safety (August 27th 2009). I consider the situation symbolic to the vulnerability of a homeless person disrespected or openly attacked by someone occupying a higher position in society. The homeless person may keep silent and try to be invisible or quite contrary - speak out, deliberately draw attention and expose him- or herself in the attempt of getting recognition. Both women choose to struggle for recognition.

The interview Brianna gave the homeless activist turned out to be just the first out of many. As a young college graduate who used to work as a secretary to a CEO for a car company, just by telling her story she undermines stereotypes of homelessness. Moreover, she openly discusses and ridicules many assumptions about street people.

Although Ruth spent the night when she was left "in the middle of nowhere" (August 27th 2009) in the darkness, hiding, she described the situation on her blog 
and criticized the careless and malicious police officer. The hitch-hiker reports all instances of mistreatment, disrespect and injustice she meets. She publishes open emails to institutions or private people who dared to offend her, because of her low social status. Ruth demands respect and argues with those who do not show it. She failed complaints against shelter workers, Grey Hound, Google. This is her way to power and agency. Sometimes the criticized institution such as a shelter sends her an apology. Traveling and blogging Ruth attempts to gain control over her life (she chooses her own roads and company) and to receive recognition as a human being who has rights and should be treated with respect regardless of her social status.

Ruth and Brianna's travel writing/blogging is their struggle for recognition. In their travelogues the homeless bloggers transform space (the road and Internet) into their place, which Yi-Fu Tuan3 defines as familiar space (73). Homeless Travel writing/blogging is a process of emplacement (Casey) of the travellers in the world (online and offline), their returning home - the place that would give them a sense of belonging. A homeless writer pursues home and citizenship, struggling for recognition: speaking up and creating dissensus (Ranciere) with the state and citizens that deny him or her full citizenship and humanity. The struggle for recognition pushes the travelogues into the personal mode of travel writing. Originally, the first person narrative in a travelogue (used as early as in the middle ages), was supposed to give it credibility; the traveller witnessed what he or she described (Thompson 38-40) Similarly homeless bloggers speaking from their experience make their perspective on stereotypes about the homeless as well as policy concerning homelessness in the US difficult to dismiss.

The first person narrative in travel writing formed the basis for the "inward turn" in the genre (98). The personal mode of homeless blogs is compatible with the need of the bloggers to (re)construct their identities after experiencing displacement. Brianna and Ruth often reflect upon themselves. After all, the struggle for recognition of one's rights requires from the person self-understanding.

Despite the activist and psychological functions of homeless blogs, they do not ignore the themes of travel writing associated with its impersonal mode such as

3 According to Tuan. Space is abstract. Place has a meaning and history. 
description of landscapes, guides or tips for future travellers, ethnographic information. However, the autobiographical travelogues emphasize subjective perspective in all elements of their story. I am going to present the Girl's Guide to Homelessness and Ruthie in the Sky as personal autobiographical travelogues, analysing motifs characteristic to the line: travel of the self, advice, landscape, ethnographic information (portrait of American society).

\section{Ruthie in the Sky and Girl's Guide to Homelessness as personal travelogues. Travel of the self}

The motif of discovering oneself and growing up on the road is characteristic for a personal travelogue.

Brianna Karp acknowledges the changes she underwent as a consequence of traumatic experiences: loss of home first, betrayal of her fiancé and a comrade in the struggles, miscarriage. At the beginning of her memoire Karp admits that she used to share stereotypes about homeless people and simply was ignoring their existence (23). At the end of her book Karp expresses gratefulness for the adventure which opened many possibilities for her (565-566). By adventure she means her homelessness, activism and affair with Matt Barnes. In the course of events Karp undergoes a transformation not only from an anonymous average girl to a homeless social media activist, an author and a celebrity, but also an independent self-aware person. Although she started blogging about homelessness before meeting Matt, her social media activism grows with the new relationship. Matt - a homeless activist from Scotland, founded an influential among homeless bloggers website Homeless Tales and had more experience in social media marketing. Therefore, he became Brianna's advisor and mentor. He helped with advertising her blog. Moreover, the transAtlantic love story of two homeless activists who met on Twitter, also attracted media attention. Becoming an activist, the girl kept looking for support and reassurance from Matt. In fact, Matt helped Brianna to understand that although there are many more destitute people in the US, she represents a new type of an American homeless person.

Brianna's social activism was entangled within her love relationship. The end of the romance threatened her status as an activist. However, it was Matt who 
excluded himself from homeless bloggers network. The way he broke with Brianna undermined his position of an activist. He showed himself as an egocentric, who does not care not only for his own fiancés safety, but also disregards collective work of the Homeless Tales bloggers.

Matt run away from Brianna who came over to Scotland to surprise him for Christmas, tell him in person she was expecting their baby and confirm her status as his fiancé._Matt who was living with his ex-girlfriend Lori and their baby-daughter did not welcome Brianna at his home. Instead he booked a hotel for her for a few nights with a promise to meet her at the Aberdeen train station on New Year's Eve. He never did appear there making his fiancé sleep rough in cold temperature and putting her life in danger. Brianna at the point had no money. The police found and rescued her from hypothermia. Nevertheless, she had a miscarriage few days later. In the meantime, Homeless Tales site went down, because Matt did not pay for its hosting. Consequently, the writers lost their life-stories.

Matt disappeared for about a month. When he finally gave a sign of life, he wrote Brianna an email asking her to accept that it was over. Matt also informed the network of writers that he and Brianna split up. In response she demanded that he returned her laptop she had lent him and the engagement ring she had bought. Since Matt was reluctant to fulfil the request and apparently attempted to present Brianna as an emotional immature girl being unable to deal with a break up, one of their mutual friends asked the girl to let him read her and Matt's correspondence. After getting familiar with it, he decided to end his friendship with Matt, but kept coorganizing World Homeless Day with Brianna and others. Although the girl was rejected as a fiancé, she got her recognition as a reasonable person and a reliable activist. After returning to the US Brianna wrote her memoire, found a job as a manager in an alternative theatre and moved into a house. Brianna claims to still be looking for home, by which she means a place that would give her a sense of belonging

Ruthie also cries for home not just housing. She gave up her social apartment in May of 2009 (Ruthie Leaves Nyssa, May 4th 2009), because she did not feel at home there without a bed and the Internet connection of which the landlord nor social workers took care, it was impossible for Ruth to turn the space of the apartment into her place - home. The hitchhiker reassumed her traveling in order to regain 
sense of independence and control over her life. Traveling and blogging about it Ruth turns space into her places. In one of the posts she boasts about plenitude and diversity of places she visited and experiences she had there only to recapitulate her life road in the following way: "I have lived, campers!" (You Saw Me Everywhere, Jan. 10th 2008).

Ruth plans to write a book about her adventures and she pursued the endeavour several times. So far neither her journey nor her book are completed. Nevertheless, the traveller has already realized some things about herself.

During one of Ruth's trips, while passing a couple hauling a yacht, her companion brings her the news, which she accepts, that her freedom threatens wealthy people attached to their expensive possessions (Ruthie on the Road, June 3rd 2008). However, Ruth realizes that homeless people's freedom is fragile, because they are often denied their rights. (Take Me Away, July 16th 2009).

Foremost, Ruthie realizes her age and health condition will not allow her to travel much longer. She claims to be tired and desperate for home now more than ever. Ruth is looking for emplacement - home which would give her recognition she finds on the road and her blog.

Experiences the bloggers gained on the road make them eligible to advice others.

\section{Advice}

The very title of Karp's memoire (Girl's GUIDE to Homelessness) implies survival tips and directions in how to manoeuvre in the precarious situation of homelessness. Karp provides her readers with useful tips concerning basic life needs, such as a place to park a trailer, the code of behaviour at a camping, hygiene, light and food when living off the greed, Internet access, free entertainment and the way to talk with the police. She does not just offer advice, but rather sets an example how to cope with basic life needs, when your home is a trailer parked in front of a store. Brianna stationed her trailer at a Walmart parking-lot, because the company has a friendly camping-policy, while in the US it is illegal to park an RV in a public space or sleep in a car. 
Ruth also shares her street-wisdom with us just by telling story of her journey. We can learn from her how to hitchhike in the US. She reviews counties on the basis of easiness to get a lift, helpfulness of their police and citizens. Many Ruth's blog posts form a guide to homeless shelters in the US. She does not hesitate to give a shelter a very harsh critique, if she feels mistreated.

A lot of tips given by both bloggers concern safety. Explaining why a visible place easily accessed such as Walmart parking-lot is a good spot for a trailer, Karp describes isolated places as dangerous, especially for women. Her "fears included being mugged, raped or killed" (179). She also mentions her dog Fezzik as a great protection for a single woman due to his massive posture as well as deep distrust towards male strangers (109).

Ruth also is quite aware of dangers of the homeless' life. She always tries to get some shelter before night. As an experienced tramp she remains cautious in presence of other homeless people, housed citizens, drivers offering her a lift and the police. This is a paradox since at the same time Ruth is looking for help form others, which requires some trust and openness. She basically does not have much choice, but to count on others' good will. However, Ruth stays on guard in shelters, because she knows that her belongings might be desirable for some of the destitute guests. In one of her posts Ruth describes her discomfort when she needed to leave her luggage in a room full of strangers in order to get a shower (Safe, My Ass! Dec. 28th 2008). In another blog entry she recalls a man who smuggled a big knife into a temporary winter shelter in Portland (Ruthie in Portland Dec. 18th 2008). Shelters rarely appear in Ruth's stories as comfortable and safe places. Ruth definitely prefers to stay in a motel, when she has this option.

Although Ruth met many nice and helpful people on the road, as a long time hitchhiker she is aware that those offering her a lift, food or a shelter may also harm her. When she loses hope for getting a ride before dusk, she often calls the police. She explains she is not afraid to do so, because her father was a policeman. Most of the time an officer would take her to a shelter or to a motel.

Karp holds the contrary to Rader's position on the police. Brianna advices homeless people not to draw police officers' attention. If you fail it, being a girl you may play the stereotypical helpless and innocent one. Being caught by a policeman in 
her car at midnight, where Brianna was trying to charge her laptop, she would lie to the officer she had an argument with a roommate, but she was going to stay with a friend tomorrow, and of course she did not realize it was illegal to sleep in one's own vehicle. The police would let her go easily.

Karp' strategy/approach towards the police is a consequence of her other general advice for homeless people to stay invisible and blend in. Karp usually kept her homelessness a secret at her temporary work places. She was able to pass for a housed citizen. Nevertheless, the girl's strategy changes dramatically into the visibility required for speaking up for one's rights as she grows up in the story.

\section{Landscape / geography}

Risk of traveling as homeless women does not stop Brianna or Ruth. The travellers give us report of places they visited. However, they mention geography and landscape predominately in the context of their emotions, thoughts and experience.

The places Karp visits, matter in her story only in relation to the girl's homelessness and/ or to her romantic affair with Matt Barnes. She describes whereabouts of the Walmart parking lot in California, where she is staying, in order to let the readers understand the everyday inconvenience a homeless person endures. Therefore, we find out that she uses a toilet at a gas station up the street from the Walmart parking lot. Next to the store a Starbucks Cafe lets Brianna charge her edevices and write her blog. The information is important, since the blog as well as the romantic relationship with another social media homeless activist make her travel.

As a homeless blogger Brianna goes to New York City for an interview. Although the trip is brief she misses her lover, who at the time was staying in California. Admiring the panorama of NYC, Brianna thinks of Matt: "I stared out the hotel window. St. Patrick's Cathedral was directly across the street, all dark, twisted, gothic stone spires and gargoyles. He would have loved this. I curled up in bed with the phone to my ear, wishing he was next to me to share it."(410). The next day girl, excited about her interview barely notices the city. She uses popular clichés referring to it: "the Big Apple" (386), and "the City that never sleeps" (408), which signifies that the inner travel is much more important in her story then geography. Similarly Brianna does not share much of Scottish landscapes with her readers. Despite her 
excitement arousing from the first transatlantic journey, the blogger mentions Aberdeen to be "exactly how you'd picture a sleepy little rural town in Scotland" (476).

Karp has no interested in sight-seeing. Her NYC trip had a business character. She travelled to Scotland in personal matters. After going through traumatic events in Scotland, she goes to London which becomes a place of her healing. Psychological aspect of Brianna's travel is more important than geography.

Traveling in its literal sense is quintessential for Ruthie. Introducing herself on her blog, she writes: "I have traveled throughout Alaska, Canada and every State in the Continental US". The tramp posts pictures taken on the road that substitute the words and verify her story of constant moving between the Western and Easter coast of the US. The photographs and short descriptions of places she passes serve as an indicator of her emotional state. In one of the posts Ruth writes:

How do I describe the euphoria of climbing to the top of that long, high hill in Washington State? How do I tell you about the beauty of that scarlet-gold sunset reflecting in my hair as I twirled around on the edge of that road? FREEDOM! (Ruthie On the Road, Update October 4th 2009).

However, the hitchhiker hardly ever exhaustively portraits towns, counties or states she is going across. Most of the time Ruth mentions the weather in the context of her health and tiredness, evaluates safety of spots she is in, help she receives from random citizens, police officers' attitude to hitchhiker in particular counties or their shelters. Ruthie travels as much across the American land as her emotions and mind. She and Brianna present their roads in a highly subjective manner. Both bloggers portray the US discussing situation of the homeless in the country and writing about people they met on the road. People's behaviour and attitudes contribute to the image of America presented in the travelogues.

\section{America}

Brianna seems to embody an American self-made (wo)man and her Scottish lover serves as an anti-American character. 
The girl's strong work ethic and belief in self-help made her keep taking temporary jobs during her homelessness. When she applied for an internship in Elle magazine she introduced herself rejecting popular stereotypes that the addressee could hold: “I'm currently homeless and living in a Walmart parking lot. I'm educated, I have never done drugs and I am not mentally ill. I have a strong employment history" (370). The Girl's Guide to Homelessness blog never had a pay-pal or other donate button, since Karp did not want to incite impressions of e-panhandling. The homeless girl cried when circumstances forced her to accept $300 \$$ from her readers after she wrote about her unexpected expenses stemming from breaking of a turbocharger in her car. Karp's followers sent her the money through Matt's PAyPal account. She admits she felt like a mooch (269).

Quite contrary to Karp's attitude, her lover from Scotland has no problem accepting things and favours he did not earn. It was him who talked Brianna into keeping the 300 \$ donation. Matt has expensive taste and would love to belong to the higher class which together with his opinion on American welfare implies idleness. Brianna quoted his comment on the US:

I'll never understand your American system. Do you realize that in the UK, everybody gets free health care, homeless people go on a short waiting list and get a free flat - and you can live there the rest of your life if you want to, never even have to get a job or anything if you don't want to. That's why I was only homeless for a short time. It's all cradle to grave there. We care about our people there (304-305).

Although Brianna does not explicitly defend the American system, she believes that with all her assets (education, a laptop and a trailer and a car) she should pull herself by the bootstraps. However, the girl claims she would love to see solutions for homeless people in worse situation.

Karp's story shows her as an industrious and persistent person with strong will. Although in California she relied on Matt's opinion concerning her activism, in Scotland she was the one who tried to push her lover back into action that would result in fulfilling Matt's plans and declaration he made when he was with Brianna in California. However, Matt who stopped taking his pills for a mental illness several 
months ago, appears extremely passive and subjugated to Lori the mother of their daughter. Lori constantly yells at him and he avoids making her angry. Although Matt's medical condition may partly explain his behaviour, the activist seems to be as a person without his own will. Briana's agency is growing up through the narrative. After recovering from trauma she remerges as Fenix from ashes and an American. She recaps her story: "One of my takeaways from a year spent navigating the seamier underbelly of the American Dream is this: If I've only got this one life, it's important to me to spend it advocating for causes I believe in, and making some kind of difference in the world, no matter how small" (565).

Brianna's travelogue evokes the 19th century travel writing about an American person's journey to the old country. She is the gullible, good-natured, hard-working and merit-oriented young American girl fascinated with the sophisticated, intelligent and charming man from the U.K. who at best turns out to be mentally ill (which would exonerate him), if he is not a sneaky, lazy, demanding and exploitative liar. However, in contrast to the picture of old country presented in the American 19th century travelogues, Great Britain does not seem to be a place of inequality, but rather of extensive welfare that can deprive people of their will. The negative vision of the UK is complicated by several facts mentioned in the memoir. First of all Lorie despite her status of a welfare recipient with rather bad manners, appears to be a decisive and powerful person since she controls and manipulates Matt. Although Lorie does not entice readers' sympathy, there are good people in Scotland and in London who helped Brianna after Matt disappeared. Finally, the United States is no longer the land of opportunity that used to be contrasted with the old world. As Karp puts it: "Americans have now collectively watched the fabled American Dream crumble around our ears, taken a major hit and been reminded in a big way, just in case we forgot, that our country and our government have feet of clay. We are not immune" (565). However, she also declares: "I have high hopes for Americans as a whole working together to rebuild what we've lost. And I have a hunch that my faith in our resiliency will be justified in the end" (565). Brianna's plan for the US is rather ambiguous. She complains about the government's inefficiency and weakness (it has feet of clay and cannot secure the American Dream) and at the same time she is not a fan of the kind of welfare that exists in the UK. 
The blogger does not explicitly write how other homeless people should be helped, but she states that she wants solutions for them. We only know that Brianna trusts the people to rebuild America. The anti-government resentment is characteristic for Americans and the homeless girl's opinion could be read as progressive (the power to the people, self-governed society) as well as classic liberal and pro-capitalist (the power to the entrepreneurial and the government as a nightguard). Anyway she embodies the American spirit of independence. Ruthie's critique of the United Sates as well as her recommendations for restoring the country are more specific. As a homeless woman in her 6os, she claims to be a living proof that the caresystem for the elderly has failed in the U.S (Because I dream American). In general the blogger criticizes American policy concerning the homeless. Foremost, Ruth denounces shelters as a mean of controlling street people (The most powerful dance, April 15, 2016. She states that affordable housing would end homelessness.

According to Ruth, "Homeless people should be empowered not enabled" (Ruthie in Portland, Update, Dec 17, 2009). She would like everybody to use their full potential, which cannot happen in the system encouraging dependency. Therefore, the blogger recommends that homeless people able to work earn their right to stay in a city shelter by performing some tasks for the city. Ruth would not allow anybody to sleep rough, which implies forcing the homeless into work. This is a surprising recommendation for a free-spirited person who finds any supervision painful and feels very entitled to others' generosity. However, the hitchhiker's health condition probably disqualifies her from work.

Ruth's declared attachment to hard work seems to be reaction to high level of consumption, which she blames for destroying social ties in the American society. She condemns the homeless pushing carts full of things, because of greed and egotism such a pile implies. In the same post she scolds those who eat in front of the hungry (Dec, 17, 2009).

The blog: Ruthie in the Sky informs its readers that consumerism makes Americans self-absorbed, attached to possessions and takes their freedom away. Consumerism and egotism appear in the travelogue to be also indirectly responsible for the lack of affordable housing. We read: 
There is a solution but there is also selfishness across this Nation. Our current presidential candidates are worth (Hillary Clinton: \$31.3 million) (Donald Trump: between $\$ 5.18$ and $\$ 10$ billion dollars) Source: Money Nation.com Are either of those individuals donating significant amounts of cash to building affordable housing for the lines of homeless people in America that need them? Nope (Because I dream American, June 18th 2016).

Nevertheless, Ruth hopes that community can be rebuilt. People who give her a hand make her hopeful. The hitchhiker strongly believes that helping a person in need is the right thing to do for a more advantaged person. Ruthie seem to desire the kind of America for which Robert Bellah is longing in his Habits of the Hearth: a community where everybody works for the common good, cares for each other, leads a good but not luxurious life. Ruth wants a house because she "dreams American" (Because I dream American).

It turns out that hitchhiker Ruth and self-made woman Brianna have a lot in common. Their travelogues form an accusation of America departing from its ideal and call upon implementing solutions that would bring it into reality. The homeless bloggers dream about going back home - the place that would be a part of themselves, gave them a sense of belonging and identity. They desire the community which would recognize and respect them regardless of their social status.

\section{Conclusions}

Homeless bloggers such as Ruth and Brianna, writing about their traveling, struggle for recognition and try to turn the indifferent to them space (road, the Internet, mainstream society) into more friendly and familiar, place-like one. The homeless women's travel writing/blogging is the process of their emplacement making themselves at home in the world.

Ruthie in the Sky and Girl's Guide to Homelessness are autobiographical homeless travelogues written during and about the displaced author's struggle for personal and group recognition. The genre serves the cause, letting the travelers focus as much on themselves (their self-discovery and development) as on the society and country (politics, values, customs) which cast them as the Other. The aspects of the 
travelogues facilitate their role in reconstructing the identity of the travelers and of the visited society. Homeless blogs are similar to both, the narratives of tramps and the "from rags to riches" myth because homeless bloggers recount stories of displaced characters experiencing downward and upward social mobility and searching for personal and American cultural identity. The homeless bloggers travel across social classes - downwards and upwards social hierarchy. Their life writing (blogging) sometimes resembling tramps' and sometimes self-made men's autobiographies, might be regarded as modalities of a story of social mobility. In this sense homeless blogs, tramps' autobiographies and the "from rags to riches" stories all belong to travel writing.

\section{References}

Anderson, Nels. The Hobo. Sociology of the Homeless Man. Chicago \& London:

Phoenix Books, The University of Chicago Press, 1967.

Arnold, Kathleen. Homelessness, Citizenship, and Identity. The Uncanniness of Late

Modernity. Albany: State University Press of New York, 2001.

Casey, Edward. The Fate of Place: A Philosophical History. University of California Press, 1977.

Clifford, James. Routes, Travel and Translation in the Late Twentieth Century.

Cambridge, MA: Harvard University Press, 1997.

Creswell, Tom. "Embodiment, Power and the Politics of Mobility: The Case of Female Tramps and Hobos", Transactions of the Institute of British Geographers, Vol. 24, No. 2 (1999), pp. 175-192, http://www.jstor.org/stable/623295. Accessed April 9th 2017.

De Pastino, Todd. Citizen Hobo. How a Century of Homelessness Shaped America. Chicago \& London: University of Chicago Press, 2003.

Hamara, Judith and Bendixen, Alfred. "Introduction: New worlds and Old Lands" The travel book and the construction of American identity, The Cambridge Companion to American Travel Writing, edited by Judith Hamara \& Alfred Bendixen. NY: Cambridge University Press, 2009, pp. 1-9.

Karp, Brianna.Girl's Guide to Homelessness. Memoir. Harlequine, 2011. e-book. 
Kusmer, Kenneth. Down and Out, on the Road. The Homeless in American History. Oxford \& New York: Oxford University Press, 2002.

Maurer, Elizabeth. "Working consensus and the rhetorical situation. The homeless blog's negotiation of public mat-genre", Genres in the Internet : Issues in the Theory of Genre. Ed. Janet Giltrow, Dieter Stein. Amsterdam \& Philadelphia: John Benjamins Publishing Company, 2009. 113-142.

Rader, Ruth. Blog. Ruthie in the Sky, http://ruthiessky.blogspot.com. Accessed April 10 th 2017.

Ranciere, Jacques. Dissensus On Politics and Aesthetics, translated by Steven Corcoran. Continuum, 2010.

Thompson, Carl. Travel Writing. London \& NY: Routledge, 2011.

Tuan, Yi-Fu. Space and Place, the Perspective of Experience. Minneapolis, London: University of Minnesota Press, 2001/ 1977.

Wyllie, Irving. The Self-made Man in America. New York: The Free Press, 1954. 